\title{
Impact of Mushroom Pleurotus tuber-regium (Rumph. ex) Fr. Extract on Lipid Profile and Testosterone of Rat
}

\author{
Sukumar Dandapat ${ }^{1, \mathrm{a}, *}$, Manoj Kumar ${ }^{2, \mathrm{~b}}$, Rakesh Ranjan ${ }^{1, \mathrm{c}}$, Manoranjan Prasad Sinha ${ }^{1, \mathrm{~d}}$ \\ ${ }^{1}$ Department of Zoology, Ranchi University, Ranchi-834008 Jharkhand, India \\ ${ }^{2}$ Department of Zoology, St. Xavier's College, Ranchi-834001 Jharkhand, India
}

*Corresponding author

A R T I C L E IN F O A B S T R A C T

Research Article

Pleurotus tuber-regium has been used as fodder and traditionally used as medicinal supplement. The aim of this study was to screen in vitro proximate biochemical composition and nutritional potentiality of $P$. tuber-regium extract for further in vivo analysis of impact of the extract on serum lipid and testosterone profile of rats. Total cholesterol, HDL cholesterol, LDL cholesterol were

Received : 18/06/2019

Accepted : 08/09/2020 measured photometrically. Testosterone was measured by chemiluminescence immune assay. $P$. tuber-regium extract contains different biochemicals such as proteins, carbohydrates, tannins, flavonoids, phenols etc. and showed highly quantified calorific value $(297.89 \pm 1.92$ calori/100g). Acute toxicity test showed no mortality and toxic behavioural symptoms. Significant decrease in total cholesterol $(75.52 \pm 0.39 \mathrm{mg} / \mathrm{dL})$, LDL cholesterol $(34.58 \pm 1.69 \mathrm{mg} / \mathrm{dL})$ and triglyceride $(81.31 \pm 1.25)$ were observed in rat group treated with $200 \mathrm{mg} / \mathrm{kg}$ dose of extract. $400 \mathrm{mg} / \mathrm{kg}$ dose of extract showed higher efficacy than $200 \mathrm{mg} / \mathrm{kg}$ dose of extract and significantly decreased total cholesterol $(72.25 \pm 1.11 \mathrm{mg} / \mathrm{dL}), \quad$ LDL cholesterol $(26.37 \pm 1.21 \mathrm{mg} / \mathrm{dL})$ and triglyceride $(69.42 \pm 0.72)$. The extract showed testosterone enhance efficacy. $400 \mathrm{mg} / \mathrm{kg}$ dose of extract showed high level testosterone $(178.96 \pm 0.68 \mathrm{ng} / \mathrm{dL})$ enhance efficacy than $200 \mathrm{mg} / \mathrm{kg}$ dose $(174.64 \pm 0.64 \mathrm{ng} / \mathrm{dL})$. Due to hypocholesterolaemia and testosterone elevating properties of $P$. tuber-regium extract, it can be said that, mushroom $P$. tuber-regium can be consumed as healthy diet supplement to maintain cholesterol level and to maintain good male reproductive health.

Mushroom

Chemical

Cholesterol

Nutrition

CVD https://orcid.org/0000-0003-3935-7798 https://orcid.org/0000-0002-7560-9094 b@dr17mk@gmail.com d@dr.mp.sinha@gmail.com
(D) https://orcid.org/0000-0003-2858-2818 (iD) https://orcid.org/0000-0002-8402-045X

\section{Introduction}

Lipids are large and diverse classes of biomolecules, associated with multiple biochemical functions such as fuelling energy production, and building blocks of plasma membrane and acts as signalling molecules during cellular communication (Tang, 2016). It has been reported that, high level of cholesterol is a major risk factor associated with cardiovascular diseases and according to the World Health Organization, cardio vascular diseases are the common causes of morbidity and mortality in the world by the year 2015 and Indian people are most affected with cardio vascular diseases amongst all ethnic population (Nag and Ghosh, 2013).

Mushrooms are called as macro-fungus with a distinctive fruiting body and they are important constituents of forest, they grow on the abundant biomolecule of hosts of this biosphere and synthesized their own biochemicals by the metabolic processes commonly called microchemical. Presently mushrooms are tremendously used as food and medicines besides their key ecological roles and they have been found effective against cancer, reduction hyper cholesteromia, stress, insomnia, asthma, allergies and diabetes, antibacterial, oxidative stress, antiviral and other properties (Wani et al., 2010; Singh, 2017).

Mushrooms of Pleurotus genus are popularly consumed by the peoples of all over the world due to their high nutritional values and some medicinal properties. The Pleurotus mushrooms are rich in proteins, essential amino acids, polysaccharides and essential fatty acids, dietary fibers, minerals, some vitamins etc. (Khan and Tania, 2012).

Plurotus tuber-regium has been used as medicinal supplement for headache, stomach ailments, cold and fever, asthma, small pox, high blood pressure as well as for weight gain and malnourishment (Oso, 1997; Afieroho et al., 2013). Aim of this work was to study impact of $P$. tuber-regium extract on lipid profile and testosterone of rat because exploration and validation of medicinal impacts of $P$. tuber-regium on lipid profile and testosterone level on mammalian model were least explored. 


\section{Materials and Methods}

\section{Collection of Mushroom}

Fresh fruiting bodies of $P$. tuber-regium were collected by the corresponding author from Manas National park of Assam, India (26 $39^{\prime} 33.9264^{\prime \prime} \mathrm{N}$ and $\left.91^{\circ} 0^{\prime} 4.0644^{\prime \prime} \mathrm{E}\right)$ and was match and identified on the basis of morphology with museum specimen by Plant Identification \& Preservation Division of Department of Botany, Gauhati University, Assam, India where a voucher specimen (No. $832 \mathrm{M}$ ) was deposited and rest of the fruiting bodies were brought to the Department of Zoology, Ranchi University, Ranchi, India for experimental work.

\section{Preparation of Extract}

Fresh mushrooms were washed and disinfected by treating with ethanol and washed again. The mushrooms were dried in shade under room temperature for six to seven days, powdered and sieved. An aliquot of the fine powder $(50 \mathrm{~g})$ was subjected to Soxhlet extraction using distilled water for aqueous extraction. The obtained extract was filtered, concentrated and dried in a rotary flash evaporator maintained at $45^{\circ} \mathrm{C}$ (Dandapat and Sinha, 2015).

\section{Mycochemical Screening}

Qualitative screening of tracable biochemicals present in the extract of $P$. tuber-regium was done following previos methods described by Arya et al. (2012). Presence of various biochemicals on the basis of function groups were detected by FTIR spectroscopy.

\section{Qualitative Analysis of Mycochemicals}

Test for carbohydrates

Presence of carbohydrate was determined by addition of few drops of Molisch's reagent to the test solutions $(1 \mathrm{mg} / \mathrm{mL}$ extract), this was then followed by addition of 1 mL concentrated $\mathrm{H}_{2} \mathrm{SO}_{4}(98 \%)$ by the side of the test tube. The mixture was then allowed to stand for two minutes and then diluted by adding $5 \mathrm{~mL}$ of distilled water. The mixture was observed for appearance of purple violet ring.

Test for glycoside

Glycoside was determined by addition of $1 \mathrm{mg} / \mathrm{mL}$ of extract to $3 \mathrm{~mL}$ of an throne reagent and was mixed properly. The mixture was observed for appearance of green colour complex.

\section{Test for proteins}

Protein was estimated by addition of $0.5 \mathrm{mg} / \mathrm{mL}$ of the extract and $2 \mathrm{~mL}$ of Bradford's reagent were left for few minutes. The mixture was observed for appearance of blue colour.

\section{Test for alkaloid}

Presence of alkaloid was determined by stirring of $1 \mathrm{mg} / \mathrm{mL}$ extract with $5 \mathrm{~mL}$ of $1 \% \mathrm{HCl}$ on hot water bath and then filtered. $1 \mathrm{~mL}$ of the filtrate was taken individually into 2 test tubes and few drops of Dragendorff's reagent were added into the test tube. The mixture was observed for appearance of dark brown colour.

\section{Test for steroid}

Presence of steroid was determined by addition of $2 \mathrm{~mL}$ concentrated $\mathrm{H}_{2} \mathrm{SO}_{4}(98 \%)$ with $2 \mathrm{mg} / \mathrm{mL}$ of extracts was mixed vigorously. The mixture was observed for initially formation of red colour followed by blue and finally development of green colour.

\section{Test for triterpene}

Triterpene was estimated by addition of $1 \mathrm{mg} / \mathrm{mL}$ extract with one drop chloroform and concentrated $\mathrm{H}_{2} \mathrm{SO}_{4}$ $(98 \%)$. The mixture was observed for formation of red colour.

\section{Test for phenol}

Presence of phenol was estimated by phenolic -catechol method. Dilute aqueous extract $(0.5 \mathrm{~mL}$ of $1: 10 \mathrm{~g} / \mathrm{L})$ was pipette out in series of test tubes and volume was made up to $3 \mathrm{ml}$ with distilled water. Folin-Ciocalteau reagent $(0.5 \mathrm{~mL})$ was added to each tube and incubated for $3 \mathrm{~min}$. at room temperature and then sodium carbonate $(20 \%$; $2 \mathrm{ml})$ solution was added, mixed thoroughly and the tubes were incubated for 1 minute in boiling water bath. The mixture was observed for the emergence of a blue-green colour.

\section{Test for flavonoid}

Flavonoid was estimated by dissolved $1 \mathrm{mg} / \mathrm{mL}$ extracts in water and later addition of $2 \mathrm{~mL}$ of the $10 \%$ aqueous sodium hydroxide and then addition of dilute hydrochloric acid as an indicator. The mixture was observed for formation and disappearance of yellow colour.

\section{Test for tannin}

Tannin was estimated by stirring $0.5 \mathrm{mg} / \mathrm{mL}$ of the extracts with $10 \mathrm{~mL}$ of distilled water and then filtered. Few drops of $1 \%$ ferric chloride solution were added to $2 \mathrm{~mL}$ of the filtrate. The mixture was observed for formation of yellow precipitate.

\section{Test for saponin}

Saponin was determined by heating $1 \mathrm{mg} / \mathrm{mL}$ extracts with alcoholic $\mathrm{KOH}$ and boiled for $1 \mathrm{~min}$ and cooled, and then the mixture was acidified with $1 \mathrm{~mL}$ of concentrate $\mathrm{HCl}$. Later few drops of $5 \% \mathrm{NaOH}$ added drop wise and observed for froth formation.

\section{Test for lipid}

$2 \mathrm{~mL}$ of extract was taken and iodine solution was added drop wise. Disappeared of original colour of iodine indicate the presence of lipid. The mixture was observed for disappearance of original colour of iodine.

\section{FTIR spectra analysis}

Fourier transform infrared (FTIR) spectra analysis was carried out IPRresting-21 (Shimadzu Corp., Kyoto, Japan) in the diffuse reflectance mode operated at are solution of $4 \mathrm{~cm}^{-1}$ in the range of $400 \mathrm{~cm}^{-1}$ to $4,000 \mathrm{~cm}^{-1}$ wave number and $\mathrm{KBr}$ as standard to identify the potential biomolecules present in fruiting body of $P$. tuber-regium extract which are responsible for reducing and capping the bio reduced silver nanoparticles. The FTIR machine was operated at $25 \pm 5^{\circ} \mathrm{C}, 60-70 \%$ humidity and $240 \mathrm{~V}$ AC (IMUSG, 2002).

\section{Nutritional Potentiality}

Calorific value of $P$. tuber-regium fruiting body was estimated on the basis of presence of total protein, total lipid and total carbohydrate in specific amount of eatable substance which together provided total metabolizable energy.

\section{Determination of crude protein}

The modified Lowry protein measurement was conducted according to the method described by Maehre (2018). The assay was carried out by diluting the extracts to $1 \mathrm{~mL}$ with $\mathrm{H}_{2} \mathrm{O}$ and adding $0.9 \mathrm{~mL}$ of solution $\mathrm{A}(2 \mathrm{~g} / \mathrm{L}$ potassium sodium tartrate $\left(\mathrm{KNaC}_{4} \mathrm{H}_{4} \mathrm{O}_{6} \cdot 4 \mathrm{H}_{2} \mathrm{O}\right)$ and $100 \mathrm{~g} / \mathrm{L}$ sodium 
carbonate $\left(\mathrm{Na}_{2} \mathrm{CO}_{3}\right)$ in $\left.0.5 \mathrm{M} \mathrm{NaOH}\right)$ before incubation for $10 \mathrm{~min}$ at $50^{\circ} \mathrm{C}$. Following this, the samples were cooled down to room temperature, added $1 \mathrm{~mL}$ of solution $\mathrm{B}(0.2$ $\mathrm{g} / \mathrm{L} \quad \mathrm{KNaC}_{4} \mathrm{H}_{4} \mathrm{O}_{6} .4 \mathrm{H}_{2} \mathrm{O}$ and $0.1 \mathrm{~g} / \mathrm{L}$ copper sulphate pentahydrate $\left(\mathrm{CuSO}_{4} .5 \mathrm{H}_{2} \mathrm{O}\right)$ in $\left.0.1 \mathrm{M} \mathrm{NaOH}\right)$ and left for $10 \mathrm{~min}$. Finally, $3 \mathrm{~mL}$ of solution $\mathrm{C}$ (Folin-Ciocalteu phenol reagent in $\left.\mathrm{H}_{2} \mathrm{O}(1: 16 \mathrm{v} / \mathrm{v})\right)$ was added before incubation for $10 \mathrm{~min}$ at $50^{\circ} \mathrm{C}$. Total protein in the sample was measured by using a standard curve made of bovine serum albumin (BSA; 0, 0.0625, 0.125, 0.25, 0.5 and $1 \mathrm{~g} /$ L) and absorbance was recorded at $650 \mathrm{~nm}$.

Determination of crude fat

$1 \mathrm{~g}$ dry mushroom powder was subjected in petroleum ether $\left(60-80^{\circ} \mathrm{C}\right)$ soluble fat was extracted in a soxhlet apparatus for about 16 hours. After extraction, the solvent was evaporated over the steam bath and the residue was oven dried at $70^{\circ} \mathrm{C}$ to a constant weight (Kaur et al., 2018). The total lipid content was determined using the below calculation.

Total Lipid $=100$ (weight of soxhlet with extractweight of dry soxhlet) / weight of mushroom sample.

\section{Determination of total carbohydrate}

The content of the crude carbohydrate was determined by the following equation (Kajendran et al., 2018).

Carbohydrate $(\mathrm{g} / 100 \mathrm{~g}$ sample $)=[100-$ weight of $($ Protein + Fat + Ash + Fibre + Moisture $)]$

Determination of Calorific value

Metabolizable energy is calculated using the below formula (Schakel et al., 1997):

Metabolizable energy $(\mathrm{Kcal} / 100 \mathrm{~g})=[(4 \times$ Total protein $)+(9 \times$ total fat $)+(4 \times$ Total carbohydrate $)]$

\section{Impact of P. Tuber-Regium Extract on Rat Model Animals}

Wistar albino rats of 175 to $200 \mathrm{~g}$ were obtained from the National Institute of Nutrition, Hyderabad, India. They were maintained under standard laboratory conditions at ambient room temperature and relative humidity, with dark-light cycle of $12 \mathrm{~h}$. Animals were fed with a commercial pallet diet (Sadguru Shri Shri Industries Pvt. Ltd. Pune, India) and water. The experiment was performed after prior approval of the Ethics committee of Ranchi University, Ranchi (Proceeding no. 46, page no. 137) for Ph.D. research project (Memo No. B/1195/18), Department of Zoology, Ranchi University, Ranchi, Jharkhand, India.

\section{Acute toxicity studies}

According to OECD (Organisation for Economic Cooperation and Development) test guideline 425 (Up and Down procedure) limited test for $P$. tuber-regium extract was performed at the single test dose $2000 \mathrm{mg} / \mathrm{kg}$ body weight (BW) on male albino rat to observe death, behavioural changes due to toxicity and decrease in BW. 5 rats were taken and were fasted (3-4hours) prior to dosing but were provided with water adlibitum. Single dose of $2000 \mathrm{mg} / \mathrm{kg} \mathrm{BW}$ of $P$. tuber-regium extract was fed to single rat through gavage using stomach tube and rats were provided with food and water adlibitum after 2hours. Similarly, 4 other rats were treated with same dose of extract (OECD, 2008; Saleem et al., 2017). The treated rats were further not received any treatment for 7 days.

Experimental design for impact of $P$. tuber-regium extract on lipid profile
Fifteen fresh animals were acquired and equally distributed among three treatment groups (Group: 1, 2 and 3) each group contain 5 animals. Two successive doses 200 $\mathrm{mg} / \mathrm{kg} \mathrm{BW}$ and $400 \mathrm{mg} / \mathrm{kg} \mathrm{BW}$ of extract were taken per the guideline of OECD (Oghenesuvwe et al., 2014). At the end of experiment ( $8^{\text {th }}$ day) animals were anaesthetized and blood was collected by orbital sinus blood sample collection method.

Group-1: This group was considered as control group and rats were not treated with mushroom extract and received single dose of $1 \mathrm{~mL}$ of distilled water daily throughout the entire period of the experiment (7days).

Group-2: This group was considered as low dose (LD) group and rats were fed single dose $\left(200 \mathrm{mg} \mathrm{kg}^{-1} \mathrm{BW}\right)$ of $P$. tuber-regium extract daily for 7 days.

Group-3: This group was considered as high dose (HD) group and rats were fed single dose (400 mg kg-1 BW) of $P$. tuber-regium extract daily for 7 days.

All the animals were sacrificed on $8^{\text {th }}$ day under light ether anaesthesia. $5 \mathrm{~mL}$ blood was collected from animals by cardiac puncture using sterile needle and syringe. The blood sample was blood was collected in evacuated voiles (SRL Diagnostic Pvt. Ltd., India) and allowed to clot for 30 min at $37^{\circ} \mathrm{C}$. The clear serum was separated by centrifuge (Wisperfuge 1384 Samson, Holland) at $2500 \mathrm{rpm}$ for $10 \mathrm{~min}$ and lipid and hormonal assay were carried out.

Table 1. Microchemical screening of $P$. tuber-regium aqueous extract $(+=$ present, $-=$ absent $)$.

\begin{tabular}{l|c}
\hline \multicolumn{1}{c}{ Microchemical } & Present / Absent \\
\hline Carbohydrate & + \\
Glycosides & + \\
Protein & + \\
Alkaloid & + \\
Steroid & + \\
Triterpene & + \\
Flavonoid & + \\
Tannin & + \\
Lipid & + \\
Saponin & + \\
Phenol & + \\
\hline
\end{tabular}

Study of impact of $P$. tuber-regium extract on lipid profile

Estimation of different parameters of cholesterol was studied photometrically (Rifa and Warnick, 2006). Estimation of serum cholesterol parameters was done on a semi-automatic chemistry analyser: SACA-19100 (MRC Ltd., Israel) operated at $0-40{ }^{\circ} \mathrm{C}, \leq 85 \%$ relative humidity and $110 \mathrm{~V} / 220 \mathrm{~V} \pm 11 \mathrm{~V} / 22 \mathrm{~V}$ alternative current using the diagnostic reagent kit by DiaSys international Pvt. Ltd. (Holzheim, Germany). Total cholesterol was measured by using Cholesterol FS* kit (Cat. No. 113009910023), high density lipoprotein (HDL) was measured by HDL-C Immuno FS* kit (Cat. No. 13521 9910 023), low density lipoprotein (LDL) was measured by LDL-C Select FS* kit (Cat. No. 141219910 026) and triglyceride was measured by Triglycerides FS* kit (Cat. No. 157109910021).

Study of impact of $P$. tuber-regium extract on Testosterone 
Serum testosterone level was measured by chemiluminescence immune assay (Anna et al., 2013) by using semi-automated chemiluminescence (CLIA) plate analyzer (Semi Auto Chemilumi Basic CLIA 2096 plus, Analytical Technologies Limited, Gujarat, India) operated at $100-240 \mathrm{VAC} \pm 10 \%, 10^{\circ} \mathrm{C}$ to $40^{\circ} \mathrm{C}$ within $15 \%-75 \%$ humidity. The assay was performed by using Acculite CLIA microwells kit (Product code: 5375-300, Monobind Inc. Lake Forest, California, USA).

\section{Statistical Analysis}

Entire statistical works were done using full proof statistical software WinSTAT (R. Fitch Software, Canal Park, Cambridge, Massachusetts, USA). Data were taken $\mathrm{N}=5$ and results were expressed as a mean \pm standard error of mean. Statistical analysis was performed by one-way ANOVA with post-hoc student's t-test, $\mathrm{P} \leq 0.05$ was considered as statistically significant.
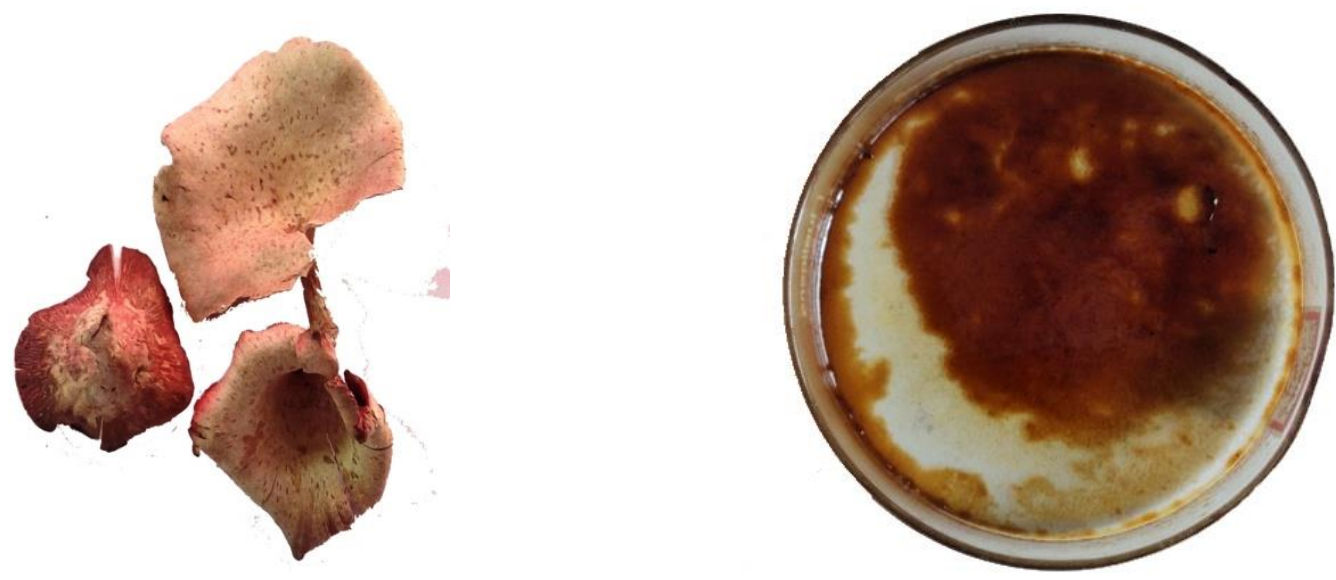

Figure 1. Fruiting bodies of P. tuber-regium and aqueous extract of P. tuber-regium

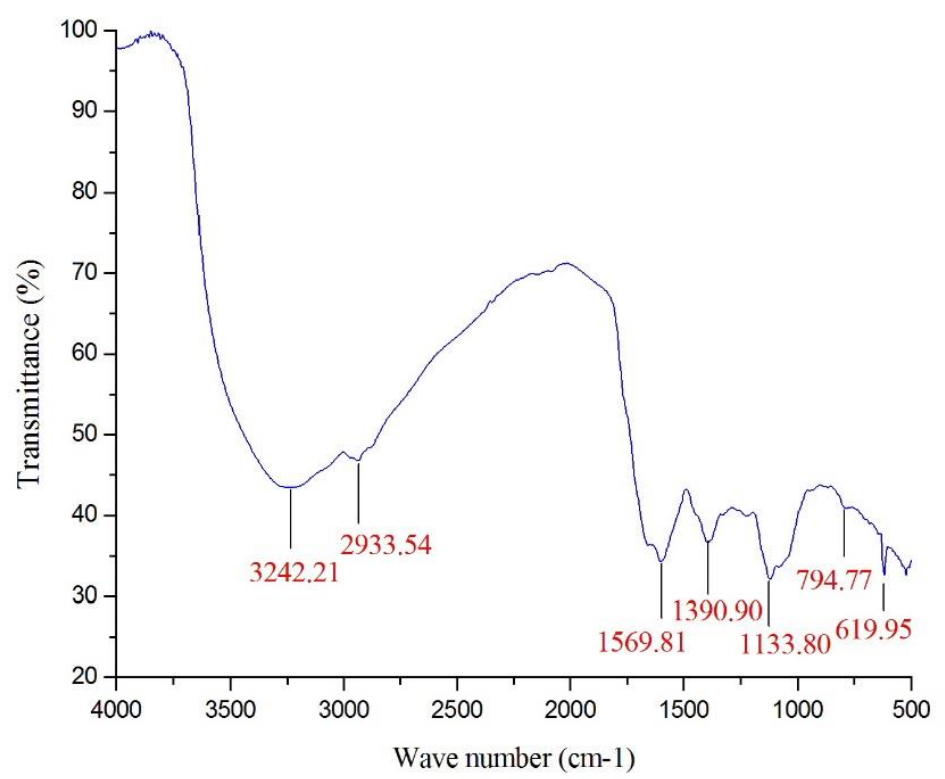

Figure 2. FTIR spectra analysis of $P$. tuber-regium extract

\section{Results}

\section{Mycochemical screening}

The fruiting body of the mushroom is cup-shaped. Pileus is deeply infundibulate, incurved margin with deeply decurrently gills, smoky dark at centre, pale and interrupted white villous form towards the margin. The pileus of the fruiting bodies are 3.4 to $7.2 \mathrm{~cm}$ in diameter. Stem or stipe is central, attached with gills, without annulus, sub cylindrical, slightly thick at base having underground tuber sclerotium. The stipeses are $2.5 \mathrm{~cm}$ to $6.3 \mathrm{~cm}$ long and
$6 \mathrm{~mm}$ to $11 \mathrm{~mm}$ in diameter, minutely smoky or pale in colour presented in figure-1. $38.5 \mathrm{~g} \%$ water soluble extractive was obtained at the end of extraction. The result shows the extract contain different mycochemicals such as carbohydrate, lipid, protein, tannin, saponin, tannin, flavonoid, phenol etc. Mushroom contains various types of biochemicals such as phenols and flavonois, tannins, proteins, polysaccharides etc. presented in table-1. Confirmation of presence of mycochemical in extract was 
done by FTIR spectroscopy analysis. The FTIR spectrum of $P$. tuber-regium is presented in figure-2. Fouriertransform infrared (FTIR) spectroscopy analysis of P. tuber-regium extract is presented in Fig. 4. The result showed major transmission broad peak at $3242.21 \mathrm{~cm}-1$ for O-H stretch of H-bond of alcohol and phenol. Peak at $2933.54 \mathrm{~cm}-1$ represented to $\mathrm{C}-\mathrm{H}$ stretch of alkanes. Peak at $1569.81 \mathrm{~cm}-1$ corresponded to $\mathrm{N}-\mathrm{H}$ stretch for primary amines and $\mathrm{N}=\mathrm{O}$ stretch for nitro methane. Peak at $1390.90 \mathrm{~cm}-1$ represented to $\mathrm{C}-\mathrm{H}$ stretch corresponded to alkane. A major peak at $1133.80 \mathrm{~cm}-1$ represented to $\mathrm{C}-\mathrm{N}$ stretch or C-O stretch for aliphatic amine or ester respectively. Peak at $794.77 \mathrm{~cm}-1$ and $619.95 \mathrm{~cm}-1$ corresponded to $\mathrm{C}-\mathrm{Cl}$ stretch for halo alkanes.

Table 2. Nutritional value of $P$. tuber-regium, $\mathrm{n}=5 \pm \mathrm{SE}, *=\mathrm{P}<0.05$.

\begin{tabular}{c|cccc}
\hline \multicolumn{3}{c|}{ Nutritional components } & Nutritional value \\
\hline Crude protein $(\mathrm{g} \%)$ & Crude carbohydrate $(\mathrm{g} \%)$ & Crude fat $(\mathrm{g} \%)$ & Crude fibre $(\mathrm{g} \%)$ & Calorific value $($ Kcal $/ 100 \mathrm{~g})$ \\
\hline $10.54 \pm 0.70^{*}$ & $58.24 \pm 2.89^{*}$ & $2.53 \pm 0.37^{*}$ & $8.64 \pm 0.66^{*}$ & $297.89 \pm 1.92$ \\
\hline
\end{tabular}

Table 3. Observation toxic behavioural patterns of rats in different groups treated with $P$. tuber-regium extract.

\begin{tabular}{|c|c|c|c|c|c|c|c|c|c|c|c|c|}
\hline \multirow{3}{*}{ Behaviour patterns } & \multicolumn{12}{|c|}{ Treatment groups of rats and observation period } \\
\hline & \multicolumn{3}{|c|}{ Control } & \multicolumn{3}{|c|}{$\begin{array}{c}200 \mathrm{mg} / \mathrm{kg} \text { of } \\
\text { Extract }\end{array}$} & \multicolumn{3}{|c|}{$\begin{array}{c}400 \mathrm{mg} / \mathrm{kg} \text { of } \\
\text { Extract }\end{array}$} & \multicolumn{3}{|c|}{$\begin{array}{l}2000 \mathrm{mg} / \mathrm{kg} \text { of } \\
\text { Extract }\end{array}$} \\
\hline & $\begin{array}{c}30 \\
\min \end{array}$ & $\begin{array}{c}24 \\
\text { Hrs. }\end{array}$ & $\begin{array}{l}\text { 7th } \\
\text { Day }\end{array}$ & $\begin{array}{l}30 \\
\min \end{array}$ & $\begin{array}{c}24 \\
\text { Hrs. }\end{array}$ & $\begin{array}{l}\text { 7th } \\
\text { Day }\end{array}$ & $\begin{array}{c}30 \\
\min \end{array}$ & $\begin{array}{c}24 \\
\text { Hrs. }\end{array}$ & $\begin{array}{l}\text { 7th } \\
\text { Day }\end{array}$ & $\begin{array}{l}30 \\
\min \end{array}$ & $\begin{array}{c}24 \\
\text { Hrs. }\end{array}$ & $\begin{array}{l}\text { 7th } \\
\text { Day }\end{array}$ \\
\hline Fur \& skin & $\mathrm{N}$ & $\mathrm{N}$ & $\mathrm{N}$ & $\mathrm{N}$ & $\mathrm{N}$ & $\mathrm{N}$ & $\mathrm{N}$ & $\mathrm{N}$ & $\mathrm{N}$ & $\mathrm{N}$ & $\mathrm{N}$ & $\mathrm{N}$ \\
\hline Eyes & $\mathrm{N}$ & $\mathrm{N}$ & $\mathrm{N}$ & $\mathrm{N}$ & $\mathrm{N}$ & $\mathrm{N}$ & $\mathrm{N}$ & $\mathrm{N}$ & $\mathrm{N}$ & $\mathrm{N}$ & $\mathrm{N}$ & $\mathrm{N}$ \\
\hline Salivation & $\mathrm{N}$ & $\mathrm{N}$ & $\mathrm{N}$ & $\mathrm{N}$ & $\mathrm{N}$ & $\mathrm{N}$ & $\mathrm{N}$ & $\mathrm{N}$ & $\mathrm{N}$ & $\mathrm{N}$ & $\mathrm{N}$ & $\mathrm{N}$ \\
\hline Breathing & I & $\mathrm{N}$ & $\mathrm{N}$ & $\mathrm{I}$ & $\mathrm{N}$ & $\mathrm{N}$ & I & $\mathrm{N}$ & $\mathrm{N}$ & I & $\mathrm{N}$ & $\mathrm{N}$ \\
\hline $\begin{array}{l}\text { Somatomotor activity \& } \\
\text { behavior pattern }\end{array}$ & $\mathrm{N}$ & $\mathrm{N}$ & $\mathrm{N}$ & $\mathrm{N}$ & $\mathrm{N}$ & $\mathrm{N}$ & $\mathrm{N}$ & $\mathrm{N}$ & $\mathrm{N}$ & $\mathrm{N}$ & $\mathrm{N}$ & $\mathrm{N}$ \\
\hline Sleep & $\mathrm{N}$ & $\mathrm{N}$ & $\mathrm{N}$ & $\mathrm{N}$ & $\mathrm{N}$ & $\mathrm{N}$ & $\mathrm{Y}$ & $\mathrm{N}$ & $\mathrm{N}$ & Y & $\mathrm{N}$ & $\mathrm{N}$ \\
\hline Convulsions \& tremors & $\mathrm{NF}$ & $\mathrm{NF}$ & $\mathrm{NF}$ & $\mathrm{NF}$ & NF & NF & $\mathrm{NF}$ & $\mathrm{NF}$ & $\mathrm{NF}$ & $\mathrm{NF}$ & $\mathrm{NF}$ & $\mathrm{NF}$ \\
\hline Itching & NF & NF & NF & $\mathrm{NF}$ & NF & NF & $\mathrm{NF}$ & NF & $\mathrm{NF}$ & $\mathrm{NF}$ & $\mathrm{NF}$ & $\mathrm{NF}$ \\
\hline Coma & NF & NF & NF & NF & NF & $\mathrm{NF}$ & $\mathrm{NF}$ & NF & $\mathrm{NF}$ & $\mathrm{NF}$ & $\mathrm{NF}$ & $\mathrm{NF}$ \\
\hline
\end{tabular}

$\mathrm{N}=$ nontoxic effect, $\mathrm{I}=$ increase, $\mathrm{NF}=$ not found, $\mathrm{Y}=$ Found

Table 4. Effect of P. tuber-regium extract of body weight of rats in different treatment groups.

\begin{tabular}{l|ccc}
\hline \multicolumn{1}{c|}{ Animal group } & Initial Body weight & Final Body weight & Mortality \\
\hline Acute toxicity groups & $179.46 \pm 1.48$ & $181.14 \pm 1.30$ & NO \\
Control & $178.61 \pm 1.49$ & $181.76 \pm 1.38$ & NO \\
$200 \mathrm{mg} / \mathrm{kg}$ treatment group & $179.92 \pm 1.54$ & $181.84 \pm 1.33$ & NO \\
$400 \mathrm{mg} / \mathrm{kg}$ treatment group & $179.26 \pm 1.42$ & $183.22 \pm 1.26$ & NO \\
\hline
\end{tabular}

\section{Acute toxicity study of P. tuber-regium extract}

Results of acute toxicity of $P$. tuber-regium extract are presented in table-3 and table-4. Acute toxicity test of $P$. tuber-regium extract revealed no behavioural changes and death of animals during the experimental period. However, insignificant increase in the final body weight of the animals treated with $200 \mathrm{mg} / \mathrm{kg}, 400 \mathrm{mg} / \mathrm{kg}$ and $2000 \mathrm{mg} / \mathrm{kg}$ were observed compared to animal group treated with vehicle.

\section{Impact of P. tuber-regium extract on lipid profile and testosterone of rats}

Results of impact of $P$. tuber-regium extract on lipid profile and testosterone level of rats is presented in figure3 to 7 . The results showed that, $200 \mathrm{mg} / \mathrm{kg}$ dose of extract $P$. tuber-regium extract significantly $(\mathrm{P} \leq 0.05)$ decreased total cholesterol $(75.52 \pm 0.39 \mathrm{mg} / \mathrm{dL})$ and $400 \mathrm{mg} / \mathrm{kg}$ dose of extract significantly $(\mathrm{P} \leq 0.05)$ decreased total cholesterol $(72.25 \pm 1.11 \mathrm{mg} / \mathrm{dL})$ compare to control treatment group of rats $(79.37 \pm 0.66 \mathrm{mg} / \mathrm{dL})$ presented in Figure-3. $200 \mathrm{mg} / \mathrm{kg}$ dose of extract $P$. tuber-regium extract significantly $(\mathrm{P} \leq 0.05)$ increased HDL cholesterol $(55.23 \pm 0.87 \mathrm{mg} / \mathrm{dL})$ and $400 \mathrm{mg} / \mathrm{kg}$ dose of extract significantly $(\mathrm{P} \leq 0.05)$ increased HDL cholesterol $(61.23 \pm 1.36 \mathrm{mg} / \mathrm{dL})$ compare to control treat group of rats $(46.35 \pm 0.93 \mathrm{mg} / \mathrm{dL})$ presented in Figure-4. $200 \mathrm{mg} / \mathrm{kg}$ dose of extract $P$. tuber-regium extract significantly $(\mathrm{P} \leq 0.05)$ decreased LDL cholesterol $(26.37 \pm 1.21 \mathrm{mg} / \mathrm{dL})$ and $400 \mathrm{mg} / \mathrm{kg}$ dose of extract significantly $(\mathrm{P} \leq 0.05) \quad$ decreased LDL cholesterol $(34.58 \pm 1.69 \mathrm{mg} / \mathrm{dL})$ compare to control treat group of rats $(39.80 \pm 1.49 \mathrm{mg} / \mathrm{dL})$ presented in Figure-5. 200mg $/ \mathrm{kg}$ dose of extract $P$. tuber-regium extract significantly $(\mathrm{P} \leq 0.05)$ decreased triglyceride $(69.42 \pm 0.72 \mathrm{mg} / \mathrm{dL})$ and $400 \mathrm{mg} / \mathrm{kg}$ dose of extract significantly $(\mathrm{P} \leq 0.05)$ decreased triglyceride $(81.31 \pm 1.25 \mathrm{mg} / \mathrm{dL})$ compare to control treat group of rats $(119.50 \pm 1.39 \mathrm{mg} / \mathrm{dL})$ Figure-6). However, $200 \mathrm{mg} / \mathrm{kg}$ dose of extract $P$. tuber-regium extract significantly $(\mathrm{P} \leq 0.05)$ increased testosterone level $(174.61 \pm 0.64 \mathrm{ng} / \mathrm{dL})$ and $400 \mathrm{mg} / \mathrm{kg}$ dose of extract also significantly $(\mathrm{P} \leq 0.05)$ increased testosterone level (178.96 $\pm 0.68 \mathrm{ng} / \mathrm{dL})$ compare to control treat group of rats $(170.77 \pm 1.36 \mathrm{ng} / \mathrm{dL})$ presented in Figure-7.

\section{Discussion}

Morphological identification of $P$. tuber-regium was done from collected fruiting body and match with the description mention given in fungi database Mycobank and 
Encyclopedia of life (Mycobank, 2015, EOL, 2015). In the present study sclerotiums were not collected and presented. Previously it has been reported P. tuber-regium (Singer.) grown on humus soil (HS), mixture of sawdust and humus soil (MSHS), sawdust (SD) had variable diameter of the pileus (HS: $7.74 \pm 2.18 \mathrm{~cm}$, MSHS: $8.65 \pm 1.75 \mathrm{~cm}, \mathrm{SD}: 5.23$ $\pm 1.53 \mathrm{~cm}$ ) and variable length of stipe (HS: $6.72 \pm 1.44 \mathrm{~cm}$, MSHS: $5.83 \pm 0.47 \mathrm{~cm}, \mathrm{SD}: 4.83 \pm 0.77 \mathrm{~cm}$ ) (Onuoha and ObiAdumanya, 2010). Present findings of morphology of $P$. tuber-regium correlates with the previous studies. Jonathan and Adeoyo (Jonathan and Adeoyo, 2011) describe the similar morphological description of $P$. tuber- regium.

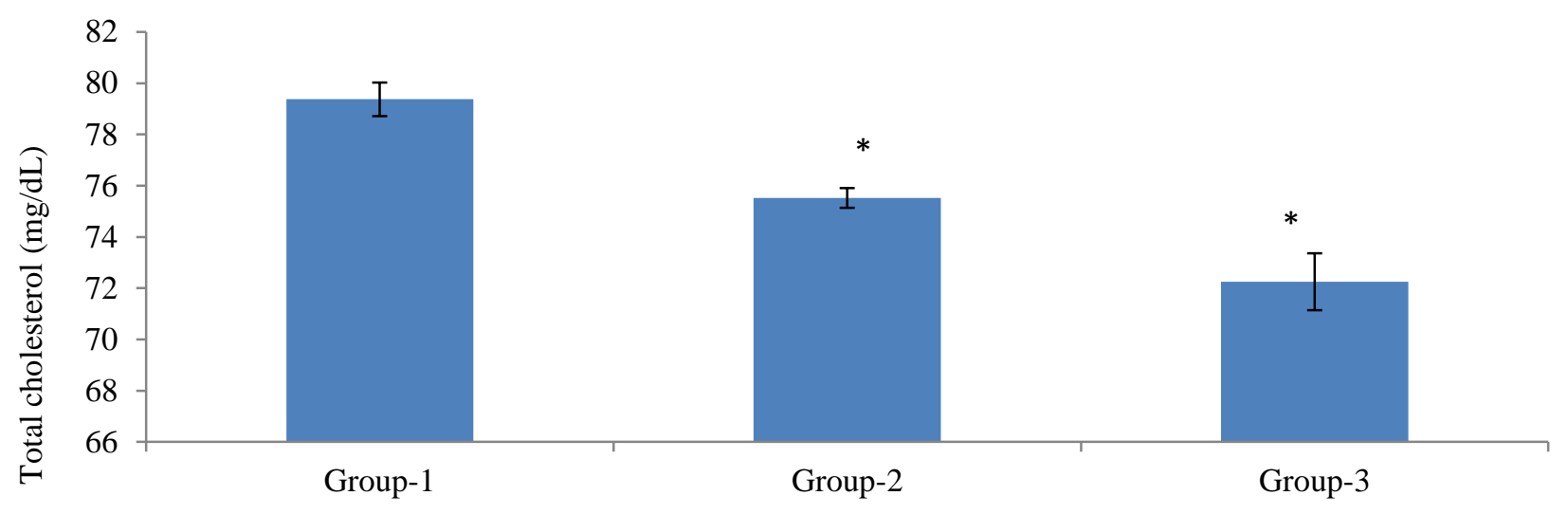

Treatment groups of rats

Figure 3. Impact of $P$. tuber-regium extract on total cholesterol of rat; Data were presented $\mathrm{N}=5 \pm \mathrm{SE}$ of mean, $*=\mathrm{P} \leq 0.05$ compared to the group-1

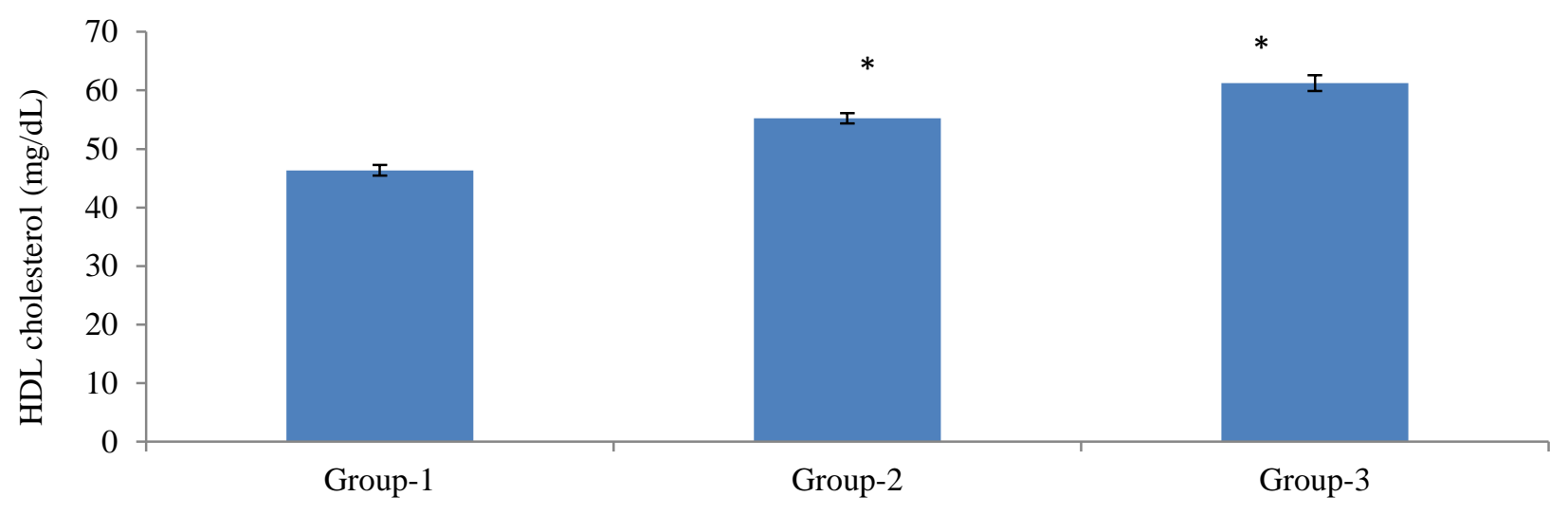

Treatment groups of rats

Figure 4. Impact of $P$. tuber-regium extract on HDL cholesterol of rat; Data were presented $\mathrm{N}=5 \pm \mathrm{SE}$ of mean, $*=\mathrm{P} \leq 0.05$ compared to the group-1.

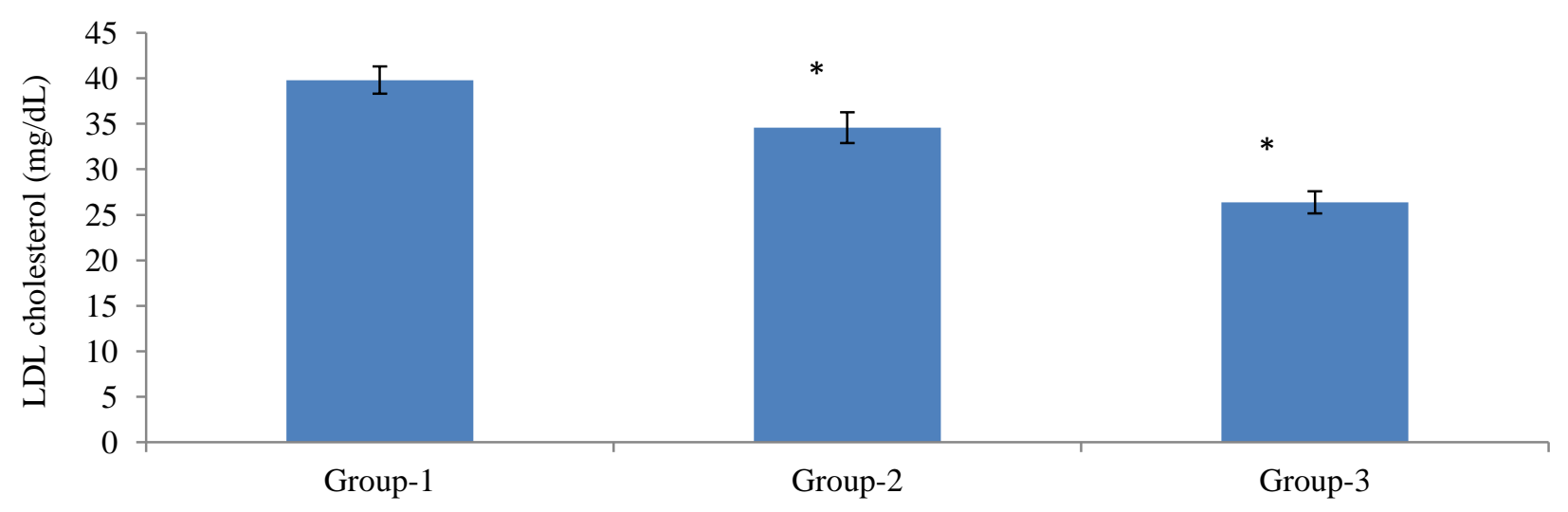

Treatment groups of rats

Figure 5. Impact of $P$. tuber-regium extract on LDL cholesterol of rat; Data were presented $\mathrm{N}=5 \pm \mathrm{SE}$ of mean, $*=\mathrm{P} \leq 0.05$ compared to the group-1. 


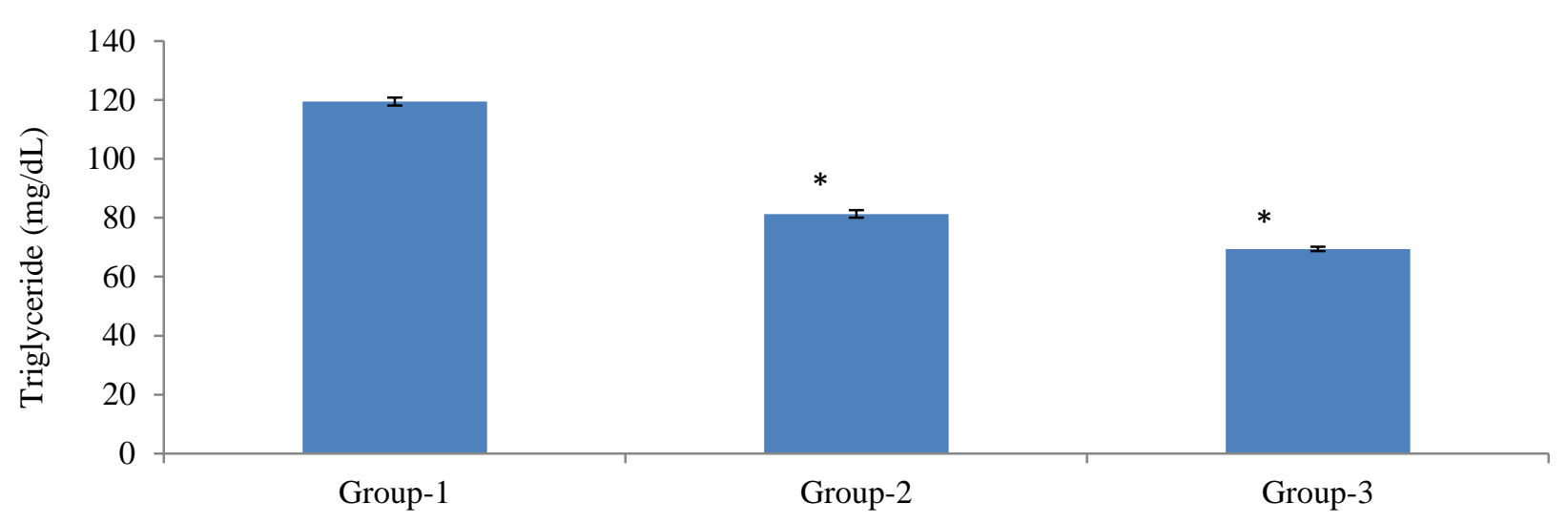

Treatment groups of rats

Figure 6. Impact of $P$. tuber-regium extract on triglyceride of rat; Data were presented $\mathrm{N}=5 \pm \mathrm{SE}$ of mean, $*=\mathrm{P} \leq 0.05$ compared to the group-1.

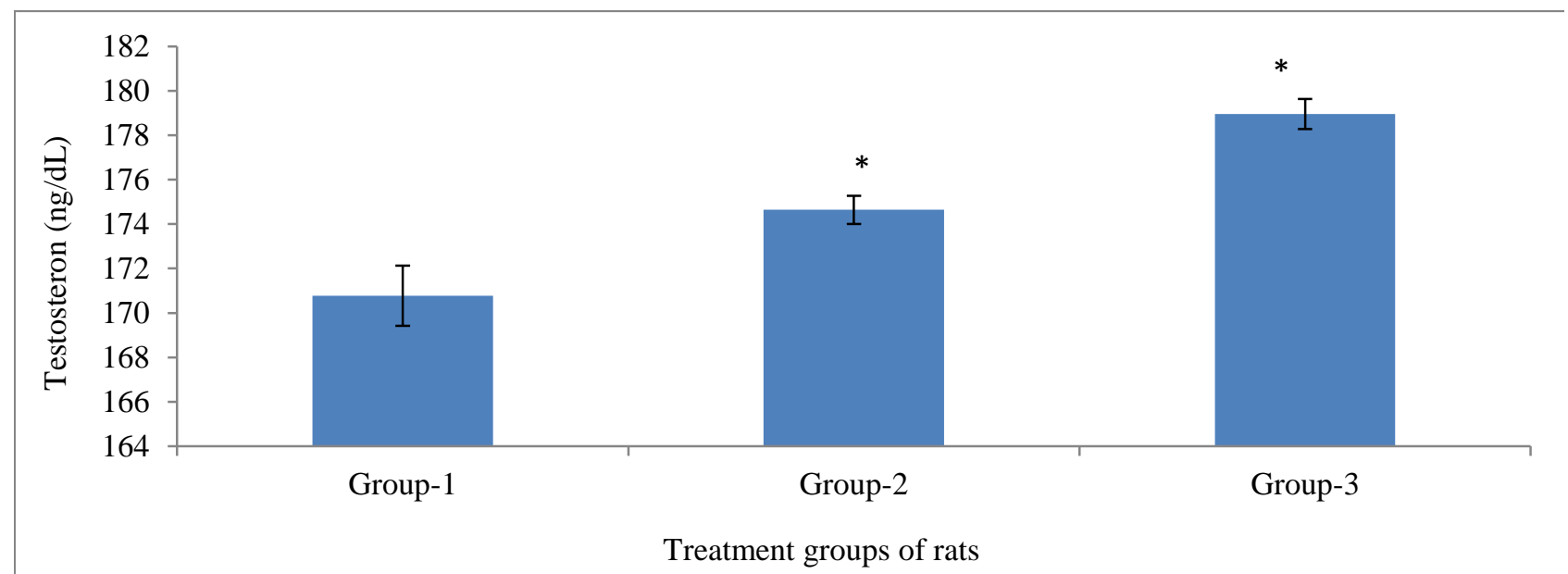

Figure 7. Impact of $P$. tuber-regium extract on testosterone of rat; Data were presented $\mathrm{N}=5 \pm \mathrm{SE}$ of mean, $*=\mathrm{P} \leq 0.05$ compared to the group-1.

Mushroom contains various types of biochemicals such as phenols and flavonois, tannins, proteins, polysaccharides etc. Previously preliminary biochemical screening of edible white button mushroom Agaricus bisporus was done and presence of biochemical such as saponins, tannins, glycosides, reducing sugar, alkaloid, flavonoid, terpenoid etc. were reported (Singh et al., 2017). FTIR analysis provides the confirmation about functional groups different mycocheicals (Reusch, 2018; Libertext, 2018; Wikipedia, 2018). In previous study FTIR analysis of crude extract of Lentinula edodes, Pleurotus ostreatus and Agaricus blazei were done and reported stretches of absorption spectra of $3600 \mathrm{~cm}^{-1}$ and $3200 \mathrm{~cm}^{-1}$ for $\mathrm{O}-\mathrm{H}$ corresponds sugar residue, $2980-2840 \mathrm{~cm}^{-1}$ represents $\mathrm{C}-\mathrm{H}$ stretching, $1200-900 \mathrm{~cm}^{-1}$ corresponds to of carbohydrates and stretching vibrations of $\mathrm{C}-\mathrm{C}, \quad \mathrm{C}-\mathrm{O}-\mathrm{C}$ for glucopyranose and $\mathrm{C}-\mathrm{O}, 1640 \mathrm{~cm}^{-1}$ and $1530 \mathrm{~cm}^{-1}$ for amides for the confirmation of presence of biochemicals such as saponins, tannins, glycosides, reducing sugar, alkaloid, flavonoid, terpenoid etc. (Radzki and Kalbarczyk, 2010). In present study FTIR analysis of P. tuber-regium extract (Figure-2) also provided transmission peaks for phenols, amines and other bioactive mycochemicals which correlates with the previous FTIR analysis of other mushroom extracts.
It has been reported that mushrooms are rich in nutritional constituents such as proteins, minerals, vitamins, fibre and carbohydrate with low fat content but mushroom has twice higher protein content than vegetables and four times than cereals (Okwulehie and Odunze, 2004). Thatoi and Singdevsachan (Thatoi and Singdevsachan, 2014) studied the nutritional composition of eight Pleurots spp. and reported carbohydrate content was higher than protein content and very low fat and good edible fibre. In previous study it has been reported edible mushrooms contains high amount of protein and carbohydrates with very low lipid content and in the present findings (Table-2) similar results were obtained which revealed mushroom $P$. tuber-regium is nutritionally beneficial for health.

It has been reported that mushroom powder increases the excretion of total lipids and cholesterol. Mevinolin a polysaccharide present in fruiting bodies of Pleurotus spp. possess hypocholesterolemic activities (Hossain et al., 2003). It has also been reported that, Pleurotus spp. reduce cholesterol absorption and reduce the activity of reduced $\mathrm{HMG}-\mathrm{CoA}$ reductase in the liver associated with cholesterol metabolism (Bobek and Ozdin, 1996). Previously it has been reported that, powder of $P$. ostreatus, $P$. citrinopileatus, $P$. pulmonarius and $P$. salmoneostramineus significantly decreases plasma, 
triglyceride, low-density lipoprotein, total lipid of hypercholesterolemic rats (Alam et al., 2011; Yoon et al., 2012). It is reported that higher HDL level is associated with better cardiovascular health and no significant effect in cardiovascular system was found further increase in HDL level after gaining its optimum level (Cesare, 2006). It has also been reported that, significant decrease in HDL level and increase level of LDL increases 10-fold and 3fold risk and of heart disease (Barter et al., 2007). In the present investigation $P$. tuber-regium extract significantly decreases the serum total cholesterol, LDL cholesterol and tiglycerides level (Table- 4) and correlates with the previous studies. Normal male reproductive function depends on testosterone and proper function of interstitial cells of testicular follicles. It has been reported that, endogenous testosterone level gradually decreases with aging in men and detrimentally effects health status (Jones, 2010). Low levels of endogenous testosterone are associated with an increased risk of atherosclerosis in men, and serum lipids are essential for atherosclerosis development due to deficiency of testosterone (Traish et al., 2009; He et al., 2013; Ruige et al., 2013). Several clinical and epidemiological studies have reported that serum testosterone levels are inversely correlated with total cholesterol and LDL cholesterol levels and it has been demonstrated markedly increased serum cholesterol levels in testosterone-deficient male mice (Hatch et al., 2012; Zhang et al., 2014). These findings indicate that testosterone metabolism is associated with regulation of serum cholesterol metabolism and in our study $P$. tuberregium significantly correlates with the previous studies.

\section{Conclusion}

$P$. tuber-regium extract contains different types of biochemicals and the extract of $P$. tuber-regium significantly decreases total cholesterol, LDL cholesterol, and triglyceride and increase HDL cholesterol and testosterone level of rats. The mushroom $P$. tuber-regium also possesses high calorific value. Thus, consumption of $P$. tuber-regium is beneficial for health and its consumption can prevent diseases associated with hyper cholesterolemia and maintain good male reproductive health. Further, isolation and screening of specific biochemicals form $P$. tuber-regium and their path associated activity studies in animal model must be done for discovery of specific compound associated with antihyper cholesterolemic activity.

\section{Acknowledgement}

Authors acknowledges Department of Zoology, Ranchi University for providing working facilities and Department of Botany, Gauhati University, Assam for their cooperation to collect and identify mushroom $P$. tuber-regium

\section{Conflict Ofinterest}

Authors declared that, there is no conflict of interest is associated with this publication.

\section{References}

Afieroho OE, Lawson L, Adedokun OM, Emenyonu N. 2013. Antituberculosis and phytochemical investigation of the dichlro-methane extract Pleurotus tuber-egium (Fies) Singer sclerotium. Int Res J Pharma. 4(1): 255-257.

Alam N, Yoon KN, Lee TS. 2011. Antihyperlipidemic activities of Pleurotus ferulae on biochemical and histological function in hypercholesterolemic rats. J Res Med Sci. 16:776-786. PMID: 22091307

Anna OC, Oladapo FO, Ugochukwu AA, Chikere OU, Bankole L, Anthony AO. 2013. Ethanolic leaf extract of Chrysophyllum albidum on sperm analysis, hormonal profile, SOD and testicular histology of adult male wistar rats. Agric Biol J N Am. 4(3): 160-165.

Arya V, Thakur N Kashyap CP. 2012. Preliminary phytochemical analysis of the extracts of Psidium leaves. J Pharmacog Phytochem. 1(1): 1-6.

Barter P ${ }^{1}$, Gotto AM, LaRosa JC, Maroni J, Szarek M, Grundy SM, Kastelein JJ, Bittner V, Fruchart JC. HDL cholesterol, very low levels of LDL cholesterol, and cardiovascular events. New England J Med 2007;357(13):1301-10. DOI: 10.1056/NEJMoa064278

Bobek P Ozdin L. 1996. Oyster mushroom (Pleurotus ostreatus) reduces the production and secretion of very low-density lipoproteins in hyper-cholesterolemic rats. J. Ernahrungswiss. 35(3): 249-252. DOI: https://doi.org/10.1007/BF01625688

Cesare SR. 2006. HDL and the progression of atherosclerosis: new insights. Europ Heart J Supplements. 31(4); 22-27. DOI: https://doi.org/10.1093/eurheartj/sul034

Dandapat S, Sinha MP. 2015. Antioxidant and anti-inflammatory activity of Pleurotus tuber-regium (Rumph. ex Fr.) Singer. Adv in Biol Res. 9(3): 140-145.

EOL. 2008.Pleurotus tuber-regium - Details - Encyclopedia of Life. Available from: http://eol.org/pages/11463022/details [Accessed 17 July 2015].

Hatch NW, Srodulski SJ, Chan HW, Zhang X, Tannock LR, King VL. 2012. Endogenous androgen deficiency enhances dietinduced hypercholesterolemia and atherosclerosis in lowdensity lipoprotein receptor-deficient mice. Gend Med 9(5): 319-28. DOI: 10.1016/j.genm.2012.08.003.

He WS, Wang MG, Pan XX, Li JJ, Jia CS, Zhang XM, Feng B. 2013. Role of plant stanol derivatives in the modulating of cholesterol metabolism and liver gene expression in mice. Food Chem. 140(1-2): 9-16. doi: 10.1016/j.foodchem. 2013.02.062

Hossain S, Hashimoto M, Choudhury EK, Alam N, Hussain S, Hasan M, Choudhury SK, Mahmud I. 2003. Dietary mushroom (Pleurotus ostreatus) ameliorates atherogenic lipid in hyper-cholesterolaemic rats. Clin Experi Pharmacol Physiol. 30: 470-475. DOI: https://doi.org/10.1046/j.14401681.2003.03857.x

IMUSG (Instruction Manual User System Guide). 2002. IRPrestige-21 (P/N 206-72010) Shimadzu Fourier Transform Infrared Spectrophotometer. Shimazu Corporation, Analytical $\&$ measuring instrument division, Koyoto, Japan. p.3:1-27. http://www.nanocenter.umd.edu/equipment/ nanoopticslab/manuals/optics-03/private/IRPrestige21\%20 Users\%20System\%20Guide.pdf (Accessed 19 January 2014).

Jonathan SG, Adeoyo OR. 2011. Collection, morphological characterization and nutrient profile of some wild mushrooms from Akoko, Ondo state, Nigeria. Natural Prod Ind J. 7(3): 128-136.

Jones TH. 2012. Testosterone deficiency: a risk factor for cardiovascular disease? Trends Endocrinol Metab. 21(8): 496-503. DOI: 10.1016/j.tem.2010.03.002.

Kajendran M, Balaji SS, Sathya S. 2018. Cultivation and determination of nutritional value on edible mushroom Pleurotus ostreatus . Euro J Biotechnol Biosci. 6(3): 40-44 
Kaur J, Sodhi HS, Jaswal RK, Kapoor S. 2015. Nutritional assessment of mutants of Calocybe indica produced by protoplast mutagenesis. J Applied and Natural Sci. 7(2): 686 - 690. doi https://doi.org/10.31018/jans.v7i2.667

Khan MD, Tania M. 2012. Nutitional and medicinal impotance of Plurotus mushrooms: an overview. Food Rev Int. 28(3): 313329. doi: https://doi.org/10.1080/87559129.2011. 637267

Libertext C. 2014. Infrared spectroscopy absorption table. Available from: https://chem.libretexts.org/Reference/ Reference_Tables/Spectroscopic_Parameters/Infrared_Spect roscopy_Absorption_Table (Accessed 25 Mar 2018).

Maehre HK, Dalheim L, Edvinsen GK, Elvevoll EO, Jensen I-J. 2018. Protein determination-method. Matters Foods. 7(5): 1-11. doi: 10.3390/foods7010005

Mycobank. Pleurotus tuber-regium (Fr.) Singer, Lilloa.1951 22:271. Available from: MB\#303985.http://www.mycobank. org/BioloMICS.aspx?TableKey $=14682616000000067 \&$ Rec $=62638 \&$ Fields $=$ All (Accessed 17 July 2015).

Nag T, Ghosh A. 2013. Cardiovascular disease risk factors in Asian Indian population: a systematic review. J Cardiovas Dis Res. 4: 222-228. doi: 10.1016/j.jcdr.2014.01.004

OECD. 2008. Organisation for Economic Co-operation and Development (OECD) guidelines for the testing chemicals Section-4. Test No. 425, Acute oral toxicity up and down procedure. 425:1-27. Available from: https://ntp.niehs.nih.gov/iccvam/suppdocs/feddocs/oecd/ oecdtg425.pdf. (Accessed 25 December 2018).

Oghenesuvwe EE, Nwoke EE, Lotanna AD. 2014. Guidelines on dosage calculation and stock solution preparation in experimental animals' studies. J Natural Sci Res. 4(18): 100-106.

Okwulehie IC, Odunze ET. Evaluation of the Myco-chemical and Mineral Composition of Some Tropical Edible Mushroom. J Sustain Agri and Environ 2004;6(1): 163-170.

Onuoha CI, Obi-Adumanya GA. 2010. Proximate analysis of Pleurotus tuber-regium (Singer) grown on the different substrates. Researcher. 2(10): 7-11.

Oso BA. 1977. Mushrooms in Yoruba mythology and medicinal practices. Economic Botany. 31: 367-371.

Radzki W, Kalbarczyk J. 2010. Water soluble polysaccharides content in three species of edible and medicinal mushrooms: Lentinula edodes, Pleurotus ostreatus, Agaricus blazei. Herba Polonica. 56(4): 31-38.

Reusch W. 2013. Inferared spectroscopy. IOCD to assist in capacity building in chemical education. Available from: https://www2.chemistry.msu.edu/ faculty/reusch/virttxtjml/ spectrpy/ infrared/infrared.htm (Accessed 17 June 2018).

Rifa N, Warnick GR. 2006. Lipids, lipoproteins, apolipoproteins and other cardiovascular risk factors. In: Burtis CA, Ashwood ER, Bruns DE, editors. Tietz text book of clinical chemistry and molecular diagnostics. 4th ed. New Delhi: Elsevier's; p.942-960. ISBN: 9781437719406.
Ruige JB, Ouwens DM, Kaufman JM. 2013. Beneficial and adverse effects of testosterone on the cardiovascular system in men. J Clin Endocrinol Metabol. 98(11): 4300-10. doi: 10.1210/jc.2013-1970.

Saleem U, Amin S, Ahmad B, Azeem H, Anwar F, Mary S. 2017. Acute oral toxicity evaluation of aqueous ethanolic extract of Saccharum munja Roxb. roots in albino mice as per OECD 425 TG. Toxicol Reports. 4: 580-585. doi: 10.1016/j.toxrep.2017.10.005.

Schakel SF, Buzzard IM, Gebhardt SE. 1997. Procedures for Estimating Nutrient Values for Food Composition Databases. J Food Compos Analysis. 10(2): 102-114. doi: https://doi.org/10.1006/jfca.1997.0527

Singh R. 2017.A review on different benefits of mushroom. J Pharma Biol Sci. 12(1): 107-111. DOI: 10.9790/3008120102107111

Singh S, Lal AA, Simon S, Ramteke PW. 2017. Efficacy of selected botanicals on biochemical constituents of white button mushroom Agaricus bisporus (Lange) Imbach. J Pharmacog Phytochem. 6(5): 2070-2076.

Tang Qi-Q. 2016. Lipid metabolism and diseases. Science Bulletin. 61(19): 1471-1472. doi: https://doi.org/10.1007/s11434-016-1174-z

Thatoi H, Singdevsachan SK. 2014. Diversity, nutritional composition and medicinal potential of Indian mushrooms: a review. African J Biotechnol. 13(4): 523-545. doi: http://dx.doi.org/10.5897/AJB2013.13446

Traish AM, Abdou R, Kypreos KE. 2009. Androgen deficiency and atherosclerosis: The lipid link. Vascul Pharmacol. 51(56): 303-13. doi: 10.1016/j.vph.2009.09.003.

Wani BA, Bodha RH, Wani AH. 2010. Nutritional and medicinal importance of mushrooms. J Med Plants Res. 4(24): 25982604. doi: 10.5897/JMPR09.565

Wikipedia. 2018. Infrared spectroscopy correlation table. Available from: https://en.wikipedia.org/ wiki/ Infrared_spectroscopy_correlation_table (Accessed 7 November 2018)

Yoon NK, Alam N, Shim MJ, Lee TS. 2012. Hypolipidemic and antiatherogenesis effect of culinary-medicinal pink oyster mushroom, Pleurotus salmoneostramineus L. Vass. (higher Basidiomycetes), in hypercholesterolemic rats. IntJ Med Mush. 14(1): 27-36. doi: 10.1615/IntJMedMushr.v14.i1.30

Zhang N, Zhang H, Zhang X, Zhang B, Wang F, Wang C, Zhao M, Yu C, Gao L, Zhao J, Guan Q. 2014. The relationship between endogenous testosterone and lipid profile in middleaged and elderly Chinese men. Eur J Endocrinol. 170(4): 487-94. doi: 10.1530/EJE-13-0802. 